\title{
KEMAMPUAN BERPIKIR KREATIF SISWA SMP DALAM MENYELESAIKAN SOAL OPEN-ENDED
}

\author{
Lilis Setianingsih ${ }^{1}$, Riawan Yudi Purwoko ${ }^{2}$ \\ ${ }^{1,2}$ Universitas Muhammadiyah Purworejo \\ Corresponding Author: lilissetianingsib2203@gmail.com1
}

\begin{abstract}
This study aims to determine students' creative thinking skills to solve arithmetic progression and series with the open-ended method. The study uses a qualitative method with a case study approach. The subjects in this study were three students of junior high school have high mathematical abilities. Data were collected by tests, interviews, field notes, and documentation. Data were analyzed using the triangulation method to gain a deeper understanding of the subject under study. The results of this study show that the student's ability to creative thinking because it meets three indicators of creative thinking, namely fluency, flexibility, and novelty. For the research conducted to get good results, the subject should find answers that can be categorized in creative thinking indicators in the form of novelty.
\end{abstract}

Keywords: Creative thinking; Problem solving; Open-ended.

How to cite: Setianingsih, L \& Purwoko, R. Y. (2019). Kemampuan Berpikir Kreatif Siswa SMP dalam Menyelesaikan Soal Open-Ended. JRPM (Jurnal Review Pembelajaran Matematika), 4(2), 143-156.

\section{PENDAHULUAN}

Dalam impelementasi kurikulum 2013 khususnya pada pembelajaran matematika, kemampuan berpikir kreatif baik siswa perlu ditingkatkan. Mrayyan (2016: 84) mengatakan bahwa kreativitas adalah kemampuan untuk membayangkan atau menciptakan sesuatu yang baru, kreativitas bukanlah kemampuan untuk menciptakan apa-apa, tetapi kemampuan untuk menghasilkan ide-ide baru dengan menggabungkan, mengubah, atau mengaplikasikan kembali ide-ide yang sudah ada. Krulik dan Rudnick dalam Siswono (2015: 2) menyatakan bahwa berpikir kreatif merupakan pemikiran yang bersifat asli dan reflektif, dengan melibatkan ide-ide baru untuk mendapatkan hasil yang baru. Salah satu perwujudan dari berpikir tingkat tinggi yaitu berpikir kreatif yang ditandai dengan penciptaan sesuatu yang baru dari hasil berbagai ide, konsep, pengalaman, maupun pengetahuan yang ada dalam pikiran seseorang.

Dalam penelitian Ayllón, Gómez \& Ballesta-Claver (2016) menunjukkan hubungan antara perkembangan berpikir matematika dan kreativitas dalam pengajuan dan penyelesaian masalah matematika. Berpikir matematika merupakan instrumen yang memungkinkan pemecahan masalah yang timbul dalam kehidupan kita sehari-hari. Alat ini didasarkan pada pembuatan konsep baru, pemecahan strategi atau cara berpikir yang berbeda. Sehingga, kreativitas merupakan suatu instrumen aktivitas dalam matematika. Dapat dikatakan bahwa 
pembelajaran dalam kurikulum 2013 telah berpusat pada siswa, artinya siswa harus berperan lebih aktif dan berpikir secara mandiri dalam pembelajaran khususnya pembelajaran matematika untuk meningkatkan berpikir kreatifnya yang masih rendah.

Rendahnya kemampuan berpikir kreatif siswa didukung oleh salah satu hasil penelitian dari Fardah (2012) yang menunjukkan kemmapuan berpikir kreatif siswa kategori tinggi sebanyak 6 siswa (20\%), kategori sedang sebanyak 10 siswa (33,33\%), dan rendah sebanyak 14 siswa (46,67\%). Hampir 50\% siswa tingkat berpikir kreatifnya rendah, dan hanya 20\% siswa yang memiliki tingkat berpikir kreatif tinggi. Fakta lain yang mendukung rendahnya berpikir kreatif siswa adalah salah satu hasil dari kompetensi matematika dan sains international yaitu Programme for International Student Assesment (PISA). Hasil PISA pada tahun 2015 menyatakan bahwa peringkat Indonesia naik tapi masih sangat rendah. Peringkat Indonesia naik dari peringkat 71 pada tahun 2012 menjadi 64 pada tahun 2015 dari 72 negara anggota Organization for Economic Cooperation and Development (OECD) (Mepnews, 2016).

Rendahnya kemampuan berpikir kreatif siswa menunjukkan bahwa kurikulum 2013 belum diterapkan dengan baik. Oleh karena itu, guru perlu memilih model, strategi, atau pendekatan pembelajaran apa yang sesuai dengan karakter siswa-siswanya dan dapat meningkatkan kualitas proses belajar mengajar di dalam kelas. Lince (2016) dalam penelitiannya yang berjudul Creative Thinking Ability to Increase Student Mathematical of Junior High School by Applying Models Numbered Head Together (NHT), menerapkan pembelajaran model NHT untuk meningkatkan kemampuan berpikir kreatif siswa SMA. Akan tetapi pembelajaran yang melibatkan kelompok belajar seperti ini kurang efektif untuk menyelidiki kemampuan berpikir kreatif siswa. Oleh karena itu peneliti memilih untuk memberikan masalah yang memiliki cara atau strategi penyelesaiannya lebih dari satu. Siswa dapat mengerjakan menggunakan cara yang telah diajarkan oleh guru atau dalam buku pendamping belajar, serta siswa bebas mengeksplorasi jawaban siswa sesuai pemikiran masing-masing. Menurut Becker dan Shimada dalam Koriyah (2015) menyebutkan bahwa open ended adalah pendekatan pembelajaran yang diformulasikan untuk menyajikan masalah terbuka dengan penyelesaian atau jawaban benar lebih dari satu.

Menurut Wijaya (2012) ketika suatu soal diberikan dalam bentuk open-ended maka siswa memiliki kesempatan untuk melakukan eksplorasi kemungkinan solusi dengan menggunakan pengetahuan dan keterampilan matematika yang mereka miliki. Menurut Kang Sup (2003) merekomendasikan bahwa pemberian tes matematika berdasarkan masalah open-ended harus diperkenalkan di sekolah, karena dapat merangsang kreativitas matematika siswa dan 
pemikiran yang berbeda.

Nohda dalam Firdaus dkk (2016) mengatakan tujuan pembelajaran dengan pendekatan open-ended adalah untuk membantu mengembangkan aktivitas yang kreatif dari siswa dan kemampuan berpikir matematis mereka dalam memecahkan masalah. Dalam penyelesaian masalah open-ended, tidak hanya menerapkan dan mempraktikkan algoritma yang disajikan oleh guru, tetapi mendorong siswa untuk menantang masalah baru dan mengembangkan pemikiran yang fleksibel. Menurut Becker \& Epstein (2006: 151) salah satu kemungkinan soal terbuka (open-ended) yaitu proses yang terbuka artinya ketika soal menekankan pada cara dan strategi yang berbeda dalam menemukan solusi yang tepat. Jenis soalnya memiliki satu solusi tunggal.

Berdasarkan uraian di atas, peneliti ingin mengetahui lebih dalam mengenai berpikir kreatif siswa dalam menyelesaikan masalah matematika menggunakan soal open-ended. Peneliti mengukur berpikir kreatif siswa menggunakan indikator menurut Silver dalam Firdausi dkk (2018) yaitu kefasihan (fluency), keluwesan (flexibility) dan kebaruan (novelty). Dalam mengukur berpikir kreatif siswa terdapat beberapa indikator berpikir kreatif yang lain seperti keaslian (originality), penguraian (elaboration) dan kepekaan (problem sensitivity). Penelitian yang dilakukan Febriyanti, Hobri \& Setiawani (2016) menunjukkan indikator berpikir kreatif yaitu kefasihan (fluency), keluwesan (flexibility), dan keaslian (originality). Keaslian (originality) dalam berpikir dapat diartikan bahwa cara yang digunakan dalam menyelesaikan soal merupakan cara murni yang berasal dari pemikiran siswa tersebut, namun tidak menutup kemungkinan siswa lain juga menggunakan cara tersebut. Berbeda dengan indikator kebaruan (novelty) disebut sebagai ciri utama dalam mengukur berpikir kreatif yang diartikan sebagai pemikiran baru yang tidak terpikirkan sebelumnya dan konsepnya berbeda dengan siswa lain.

\section{METODE PENELITIAN}

Penelitian ini merupakan penelitian kualitatif menggunakan pendekatan studi kasus. Penelitian dilaksanakan pada bulan Oktober 2018 sampai Mei 2019. Subjek penelitian ini adalah siswa kelas VIII berkemampuan matematika tinggi yang dipilih menggunakan teknik purposive, berdasarkan nilai murni PTS matematika yang mendapatkan nilai $>90$. Subjek yang telah terpilih kemudian diberikan soal tes barisan dan deret aritmatika. Soal di desain untuk memunculkan ide-ide kreatif para subjek penelitian.

Peneliti menetapkan fokus penelitian, memilih informan sebagai sumber data, melakukan pengumpulan data, menilai kualitas data, analisis data, menafsirkan data dan 
membuat kesimpulan atas temuannya. Instrumen dalam penelitian ini telah divalidasi oleh dosen pendidikan matematika yang bersangkutan dan guru matematika dimana peneliti melakukan penelitian untuk menguatkan keabsahan instrumen. Dalam penelitian ini, peneliti menggunakan instrumen pendukung pada pengumpulan data yaitu soal tes, wawancara tidak terstruktur, dan catatan lapangan. Adapun soal barisan dan deret aritmatika disajikan pada gambar 1 berikut.

1. Pak Hadi sedang menumpuk batu bata yang tingginya 10 tingkat membentuk sebuah piramida. Pada tumpukan batu bata tersebut, banyak batu bata paling bawah ada 10 buah, tepat di atasnya ada 9 buah, dan seterusnya setiap tumpukan di atasnya selalu berkurang 1 buah dari jumlah batu bata di tingkat bawahnya. Berapa batu bata yang diperlukan Pak Hadi untuk membuat sebuah piramida? Sudah terjawab? Jika sudah, coba kerjakan dengan cara yang lain!

2. Rina menghitung banyaknya bilangan asli antara 1 sampai 100 yang habis dibagi 6. Berapa jumlah seluruh bilangan diantara 1 sampai 100 yang habis dibagi 6 ? Sudah terjawab? Jika sudah, coba kerjakan dengan cara yang lain!

Gambar 1. Soal barisan dan deret aritmatika dengan metode open-ended

Teknik pengumpulan data yang digunakan dalam penelitian ini dengan pemberian soal tes, melakukan wawancara, catatan lapangan dan dokumentasi berupa cuplikan hasil pekerjaan siswa. Teknik analisis data yang digunakan mengacu pada model Miles dan Huberman (Sugiyono, 2012) yaitu: (1) Data Reduction (Reduksi Data), (2) Data Display (Penyajian Data), (3) Conclusion Drawing/Verification (Penarikan Kesimpulan). Sedangkan teknik pemeriksaan keabsahan data yang digunakan yaitu (1) Uji credibilty, (2) Uji dependability (Sugiyono, 2012). Analisis tentang kemampuan berpikir kreatif mengacu pada 3 bentuk data dalam kegiatan penelitian ini yaitu vignette berupa cuplikan hasil pekerjaan subjek, hasil wawancara dan hasil catatan lapangan. Tiga data ini akan menjadi tolok ukur peneliti dalam menyimpulkan bagaimana kemampuan berpikir kreatif siswa dalam menyelesaikan masalah barisan dan deret aritmatika melalui soal open-ended.

\section{HASIL DAN PEMBAHASAN}

Hasil penyelesaian soal yang dilakukan subjek pertama $\left(S_{1}\right)$, subjek kedua $\left(S_{2}\right)$ dan subjek ketiga $\left(S_{3}\right)$ terlihat pada analisis berikut:

\section{Subjek pertama $\left(S_{1}\right)$}

Langkah pertama yang dilakukan oleh $S_{1}$ ketika menyelesaikan soal nomor 1 terlihat dari hasil pekerjaan seperti tampak pada gambar 2 berikut. 


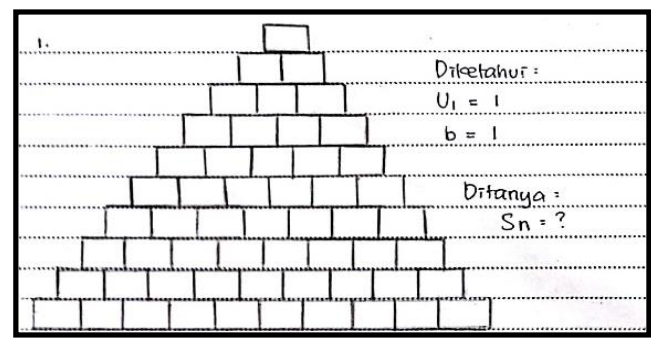

Gambar 2. Subyek $S_{1}$ memahami masalah

$S_{1}$ mampu menggambar piramida dengan benar dan mengetahui apa yang diketahui dan apa yang ditanyakan, sehingga $S_{1}$ dapat memahami masalah dengan baik. Selanjutnya, langkah kedua yang dilakukan $S_{1}$ yaitu menyelesaikan masalah menggunakan rumus. Hal ini terlihat dari hasil pekerjaan seperti tampak pada gambar 3 berikut.

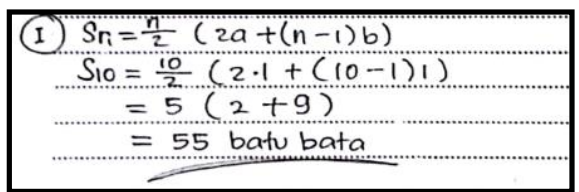

Gambar 3. Subyek $S_{1}$ menyelesaikan masalah dengan cara pertama

$S_{1}$ dapat menghubungkan data yang belum diketahui pada soal dengan baik dan menyelesaikannya sesuai rencana. Hasilnya benar serta menghitung lancar, sehingga dapat dikatakan bahwa $S_{1}$ mampu menunjukkan indikator berpikir kreatif kefasihan (fluency) dalam menyelesaikan soal.

Langkah berikutnya yang dilakukan $S_{1}$ yaitu menggunakan cara lain untuk menyelesaikan soal. Hal ini terlihat dari hasil pekerjaan $S_{1}$ seperti tampak pada gambar 4 berikut.

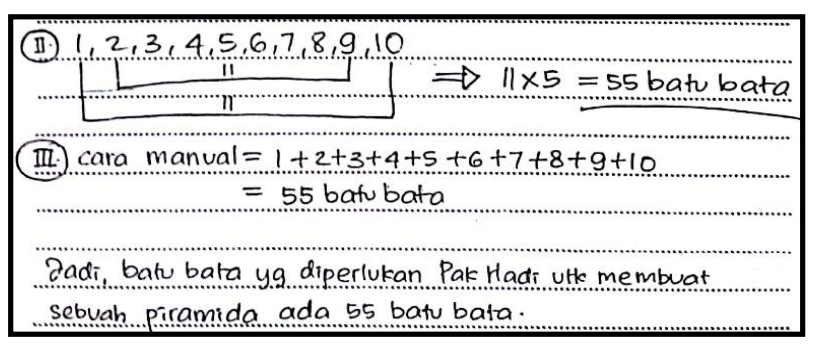

Gambar 4. Subyek $S_{1}$ menyelesaikan masalah dengan cara lain

$S_{1}$ dapat menggunakan cara lain dan hasilnya sama dengan menyelesaikan soal dengan cara pertama, sehingga $S_{1}$ mampu menunjukkan indikator berpikir kreatif keluwesan (flexibility). Langkah pertama yang dilakukan oleh $S_{1}$ ketika menyelesaikan soal nomor 2 terlihat dari hasil pekerjaan seperti tampak pada gambar 5 berikut.

\begin{tabular}{|c|l|}
\hline 2. Diketahur. & Ditanya: \\
$6,12,18, \ldots, 96$ & $S_{n}=?$
\end{tabular}

Gambar 5. Subyek $S_{1}$ memahami masalah 
$S_{1}$ memahami soal nomor 2 dengan menuliskan apa yang diketahui dan apa yang ditanyakan. Selanjutnya, $S_{1}$ menyelesaikan masalah cara pertama dengan mencari $n$ terlebih dahulu untuk menghitung $\mathrm{S}_{\mathrm{n}}$. Hal ini terlihat dari hasil pekerjaan seperti tampak pada gambar 6 berikut.

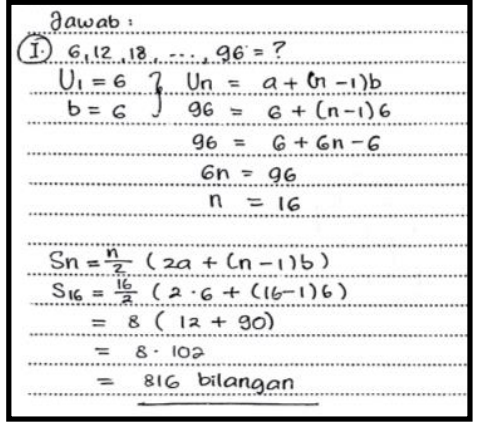

Gambar 6. Subyek $S_{1}$ menyelesaikan masalah dengan cara pertama

Hasil pekerjaan $S_{1}$ menunjukkan bahwa memperoleh nilai $n$ kemudian menghitung $\mathrm{S}_{\mathrm{n}}$ dengan tepat serta menghitung lancar, sehingga dapat dikatakan bahwa $S_{1}$ mampu menunjukkan kefasihan (fluency) dalam menyelesaikan soal. Langkah berikutnya yang dilakukan $S_{1}$ yaitu menggunakan cara lain untuk menyelesaikan soal. Hal ini terlihat dari hasil pekerjaan $S_{1}$ seperti tampak pada gambar 7 berikut.

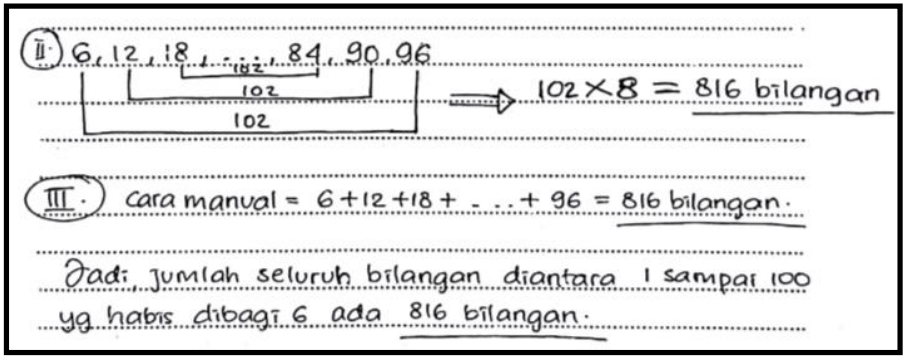

Gambar 7. Subyek $S_{1}$ menyelesaikan masalah dengan cara lain

Setelah menyelesaikan soal dengan menghitung lancar dan dapat menggunakan cara lain dalam menyelesaikan soal dengan jawaban yang benar, maka $S_{1}$ memenuhi indikator kemampuan berpikir kreatif kefasihan (fluency) dan keluwesan (flexibility). Untuk indikator kemampuan berpikir kreatif kebaruan (novelty), $S_{1}$ belum dapat memenuhinya.

\section{Subjek kedua $\left(S_{2}\right)$}

Langkah pertama yang dilakukan oleh $S_{2}$ ketika menyelesaikan soal nomor 1 terlihat dari hasil pekerjaan seperti tampak pada gambar 8 berikut. 


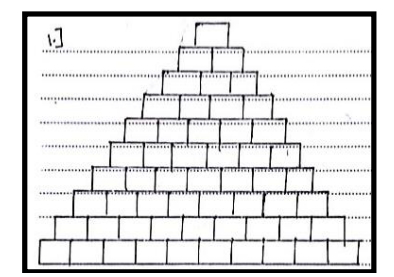

Gambar 8. Subyek $S_{2}$ memahami masalah

$S_{2}$ dapat dikatakan mampu memahami masalah dengan menggambar piramida. Tanpa menuliskan apa yang diketahui dan ditanyakan, langkah selanjutnya yang dilakukan oleh $S_{2}$ yaitu langsung menjawab alternatif 1 . Hal ini terlihat dari hasil pekerjaan seperti tampak pada gambar 9 berikut.

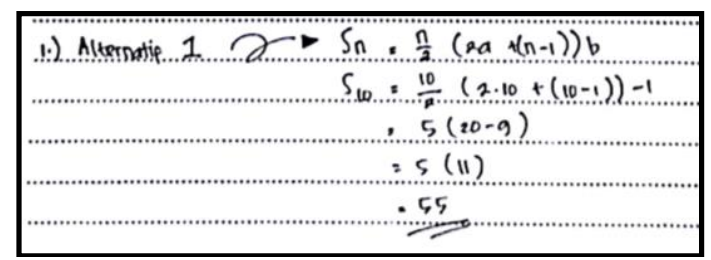

Gambar 9. Subyek $S_{2}$ menyelesaikan masalah dengan cara pertama

$S_{2}$ dapat menghubungkan data yang belum diketahui pada soal dengan baik dan menyelesaikannya sesuai rencana. Hasil pekerjaanya tepat dan menghitung lancar, sehingga dapat dikatakan bahwa $S_{2}$ mampu menunjukkan indicator berpikir kreatif fluency dalam menyelesaikan soal. Langkah selanjutnya yang dilakukan $S_{2}$ adalah mencari alternatif jawaban lain, seperti tampak pada gambar 10 berikut.
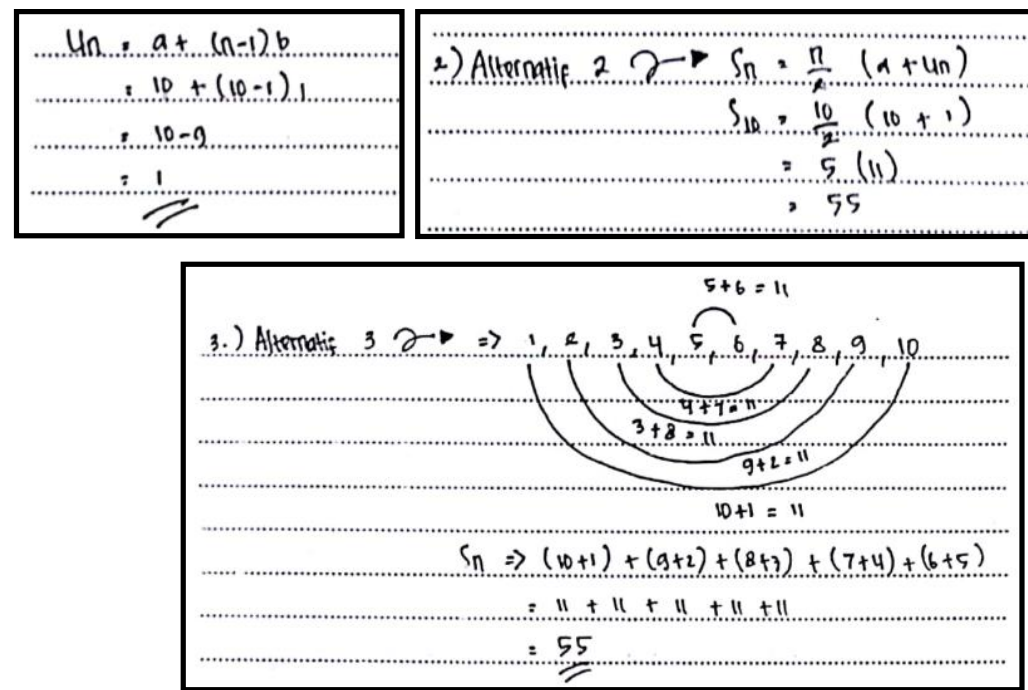

Gambar 10. Subyek $S_{2}$ menyelesaikan masalah dengan cara lain

$S_{2}$ mampu menggunakan cara lain dengan hasil yang sama dengan menyelesaikan soal cara pertama, sehingga $S_{2}$ mampu memenuhi indikator berpikir kreatif flexibility.

Langkah pertama yang dilakukan oleh $S_{2}$ ketika menyelesaikan soal nomor 2 terlihat dari hasil pekerjaan seperti tampak pada gambar 11 berikut. 


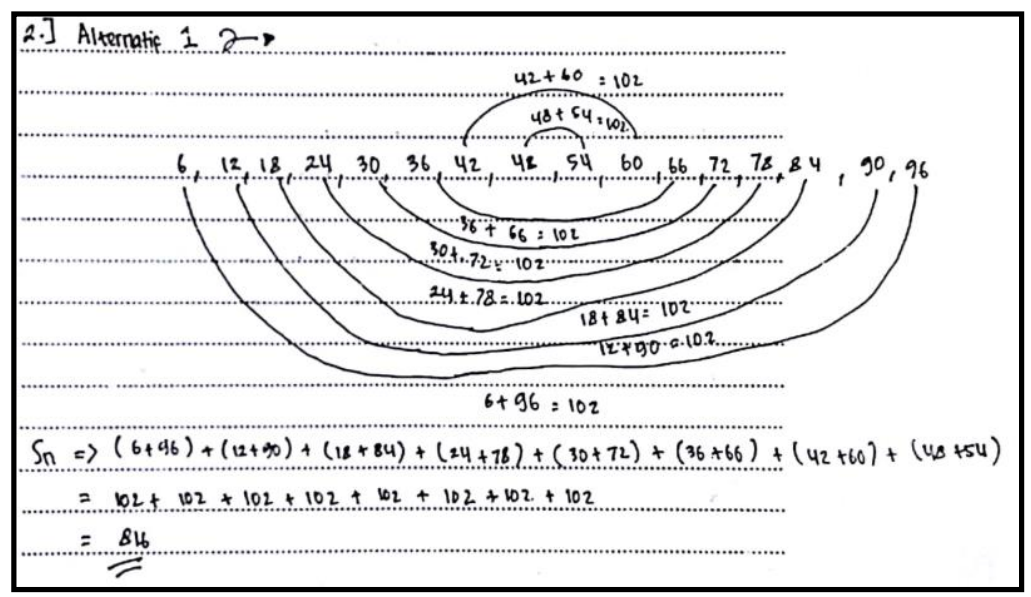

Gambar 11. Subyek $S_{2}$ menyelesaikan masalah dengan cara pertama

$S_{2}$ langsung menjawab alternatif 1 dengan cara mendaftar anggota bilangan 1-100 yang habis dibagi 6, kemudian menghitungnya secara manual dan menunjukkan hasil yang benar dengan menghitung lancar. Sehingga, $S_{2}$ memenuhi indikator fluency. Selanjutnya, langkah kedua yang dilakukan oleh $S_{2}$ yaitu mencari alternatif jawaban lain. Namun sebelumnya mencari nilai $n$ terlebih dahulu, hal ini terlihat dari hasil pekerjaan seperti tampak pada gambar 12 berikut.
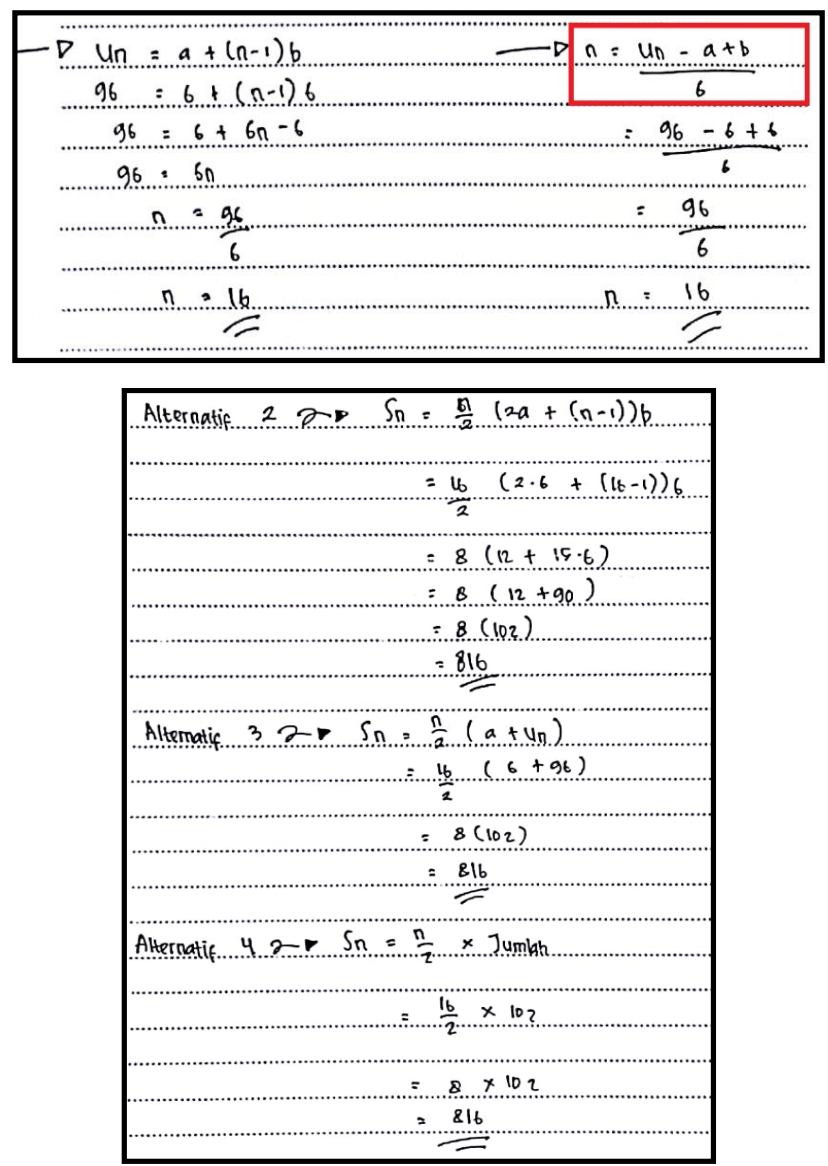

Gambar 12. Subyek $S_{2}$ menyelesaikan masalah dengan cara lain 
Hasil pekerjaan $S_{2}$ di atas menunjukkan bahwa $S_{2}$ telah mampu menghitung dengan lancar, sehingga $S_{2}$ telah memenuhi indikator berpikir kreatif fluency. $S_{2}$ juga mampu menggunakan cara lain dalam menyelesaikan soal tersebut serta mendapatkan hasil yang tepat dan benar sehingga $S_{2}$ memenuhi indikator berpikir kreatif flexibility serta $S_{2}$ mampu menghasilkan cara baru dalam proses penyelesaian soal. Pemikiran baru yang dihasilkan oleh $S_{2}$ merupakan ciri kebaruan (novelty), karena cara yang digunakan berdasarkan pemikiran $S_{2}$ sendiri dan belum ada subjek lain yang menggunakan cara tersebut. Sehingga, $S_{2}$ dapat memenuhi indikator berpikir kreatif novelty.

\section{Subjek ketiga $\left(S_{3}\right)$}

Langkah pertama yang dilakukan oleh $S_{3}$ ketika menyelesaikan soal nomor 1 terlihat dari hasil pekerjaan seperti tampak pada gambar 13 berikut.

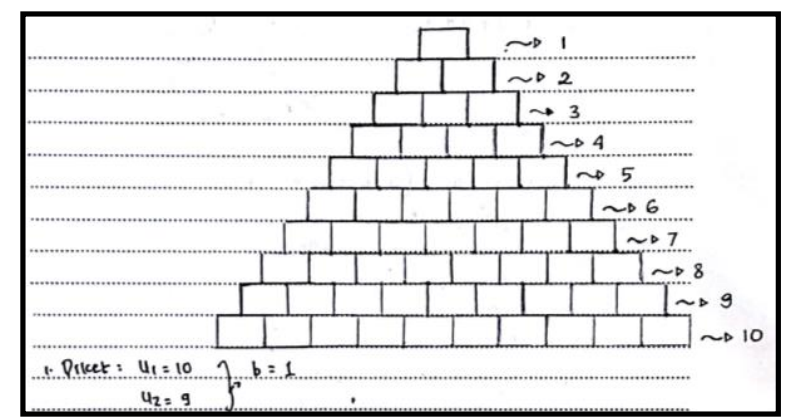

Gambar 13. Subyek $S_{3}$ memahami masalah

$S_{3}$ sudah dapat memahami masalah dengan menggambar piramida dan menuliskan apa yang diketahui. Setelah $S_{3}$ memahami masalah, $S_{3}$ menyelesaikan masalah dengan cara pertama terlihat seperti tampak pada gambar 2 berikut..

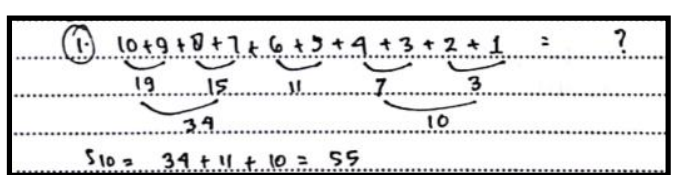

Gambar 14. Subyek $S_{3}$ menyelesaikan masalah dengan cara pertama

$S_{3}$ dapat menghitung manual dengan lancar dan memperoleh hasil yang benar, sehingga $S_{3}$ mampu memenuhi indikator berpikir kreatif fluency dalam menyelesaikan soal. Langkah berikutnya yang dilakukan $S_{3}$ yaitu menggunakan cara lain untuk menyelesaikan soal. Hal ini terlihat dari hasil pekerjaan $S_{3}$ seperti tampak pada gambar 15 berikut. 


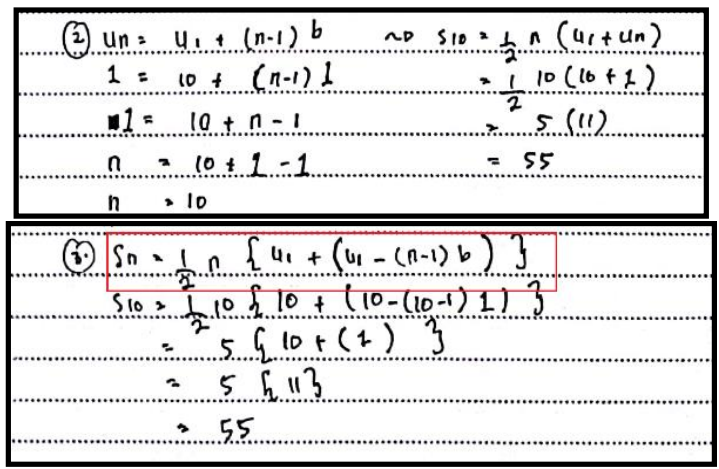

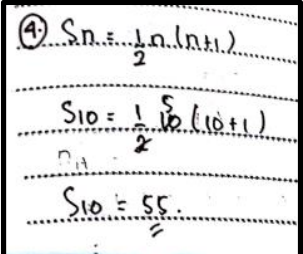

Gambar 15. Subyek $S_{3}$ menyelesaikan masalah dengan cara lain

$S_{3}$ dapat menggunakan cara lain untuk menyelesaikan soal serta memperoleh hasil yang benar, sehingga $S_{3}$ mampu memenuhi indikator berpikir kreatif flexibility. Dari penyelesaian soal menggunakan cara lain, $S_{3}$ mampu menggunakan idenya untuk menyelesaikan soal dengan rumus baru dan berbeda dengan subjek lain. Sehingga, $S_{3}$ dapat memenuhi indikator berpikir kreatif novelty.

Langkah pertama yang dilakukan oleh $S_{3}$ ketika menyelesaikan soal nomor 2 terlihat dari hasil pekerjaan seperti tampak pada gambar 16 berikut.

$$
\text { 2. Plket: } \begin{aligned}
u_{1}=6 \\
u_{2}=12
\end{aligned}
$$

Gambar 16. Subyek $S_{3}$ memahami masalah

$S_{3}$ dapat memahami masalah dengan menuliskan apa yang diketahui pada soal. Setelah itu, langkah kedua yang dilakukan $S_{3}$ yaitu menyelesaikan soal menggunakan rumus. Hal ini terlihat dari hasil pekerjaan seperti tampak pada gambar 17 berikut.

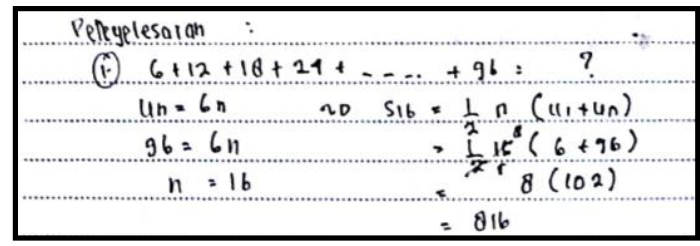

Gambar 17. Subyek $S_{3}$ menyelesaikan masalah dengan cara pertama

$S_{3}$ dapat menghubungkan data yang belum diketahui pada soal dan merencanakan penyelesaian dengan menghitung lancar dan hasilnya benar, maka $S_{3}$ telah memenuhi indikator berpikir kreatif fluency. Kemudian, $S_{3}$ mencari alternatif penyelesaian seperti tampak pada gambar 18 berikut. 


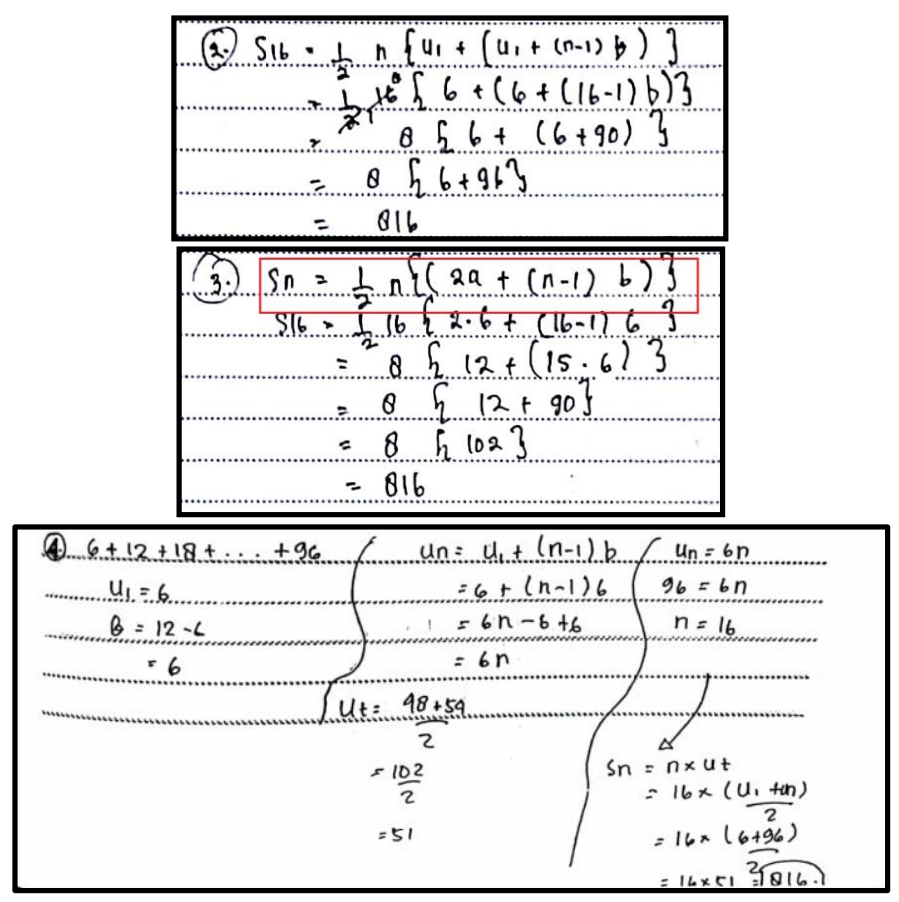

Gambar 18. $S_{3}$ menyelesaikan masalah dengan cara lain

$S_{3}$ dapat menggunakan cara lain untuk menyelesaikan soal serta memperoleh hasil yang benar, sehingga $S_{3}$ mampu menunjukkan indikator berpikir kreatif flexibility. Dari penyelesaian soal menggunakan cara lain, $S_{3}$ mampu menggunakan idenya untuk menyelesaikan dengan rumus yang sebelumnya belum pernah mengetahui dan berbeda dengan subjek lain. Sehingga, $S_{3}$ dapat memenuhi indikator berpikir kreatif novelty.

Dari analisis ketiga subjek di atas, pencapaian indikator berpikir kreatif disajikan dalam bentuk tabel sebagai berikut.

Tabel 1. Pencapaian Indikator Berpikir Kreatif

\begin{tabular}{cllll}
\hline \multirow{2}{*}{ Subjek } & \multicolumn{4}{c}{ Pencapaian Indikator Berpikir Kreatif } \\
\cline { 2 - 5 } & \multicolumn{3}{c}{ Soal nomor 1 } & \multicolumn{1}{c}{ Soal nomor $\mathbf{2}$} \\
\hline$S_{1}$ & a. & Kefasihan (fluency) & a. & Kefasihan (fluency) \\
& b. & Keluwesan (flexibility) & b. & Keluwesan (flexibility) \\
\hline$S_{2}$ & a. & Kefasihan (fluency) & a. & Kefasihan (fluency) \\
& b. & Keluwesan (flexibility) & b. & Keluwesan (flexibility) \\
& & & c. & Kebaruan (novelty) \\
\hline$S_{3}$ & a. & Kefasihan (fluency) & a. & Kefasihan (fluency) \\
& b. & Keluwesan (flexibility) & b. & Keluwesan (flexibility) \\
& c. & Kebaruan (novelty) & c. & Kebaruan (novelty) \\
\hline
\end{tabular}

Indikator kemampuan berpikir kreatif kefasihan (fluency) dan keluwesan (flexibility) dapat dipenuhi oleh subjek secara keseluruhan. Namun, untuk indikator utama yang merupakan ciri utama dalam berpikir kreatif berupa kebaruan (novelty) pada kedua soal hanya dipenuhi oleh subjek ketiga. Subjek kedua dapat memenuhi kebaruan dalam 
merencanakan penyelesaian pada soal nomor 2 saja. Namun secara keseluruhan indikator berpikir kreatif yang digunakan peneliti dapat dipenuhi oleh subjek penelitian yang dipilih.

Subjek pertama dalam menyelesaikan soal nomor 1 dan 2 menggunakan 3 cara. Cara pertama mencari $S n$ menggunakan rumus $S n=\frac{n}{2}(2 a+(n-1) b)$ dan mencari nilai $n$ menggunakan rumus $U_{n}=a+(n-1) b$, subjek pertama dapat menghitung secara lancar dan mendapatkan hasil yang benar sehingga memenuhi indikator berpikir kreatif fluency. Kemudian dia mencari alternatif penyelesaian lain yaitu cara kedua dan ketiga menggunakan cara bilangan (numerik) dan cara manual. Hasil yang diperoleh pada penghitungan cara kedua dan ketiga sama dengan cara pertama, maka subjek pertama memenuhi indikator berpikir kreatif flexibility. Karena tidak ada rumus baru yang dihasilkan dari idenya sendiri, maka subjek pertama belum bisa memenuhi indikator berpikir kreatif novelty. Seperti pada penelitian sebelumnya yang dilakukan oleh Laela (2017) yang menunjukkan bahwa belum ada subjek yang memenuhi ciri kebaruan (novelty),

Subjek kedua dalam menyelesaikan soal nomor 1 menggunakan 3 cara dan soal nomor 2 menggunakan 4 cara. Cara pertama pada soal nomor 1 menggunakan rumus $S n=\frac{n}{2}(2 a+(n-1) b)$. Subjek kedua dapat menghitung secara lancar dan mendapatkan hasil yang benar sehingga memenuhi indikator berpikir kreatif fluency, kemudian cara yang kedua mencari nilai $U_{n}$ terlebih dahulu menggunakan rumus $U_{n}=$ $a+(n-1) b$ untuk mencari $S n=\frac{n}{2}\left(a+U_{n}\right)$ dan cara yang ketiga menghitung secara manual. Dari cara kedua dan ketiga, hasilnya sama dengan cara yang pertama. Sehingga, subjek kedua memenuhi flexibility. Sedangkan pada soal nomor 2, ketiga cara yang digunakan sama dengan nomor 1 ditambah dengan rumus $S n=\frac{n}{2} \times J u m l a h$ dan menghitung nilai $n$ dengan menggunakan rumus $n=\frac{U_{n}-a+b}{6}$. Rumus tersebut dihasilkan dari ide subjek sendiri yang sebelumnya belum pernah terpikirkan dan berbeda dengan subjek lain, sehingga subjek kedua memenuhi indikator berpikir kreatif novelty pada soal nomor 2 .

Subjek ketiga dalam menyelesaikan soal nomor 1 dan soal nomor 2 menggunakan 3 cara. Untuk cara pertama pada nomor 1 menghitung jumlah secara manual dengan lancar dan benar, sehingga subjek ketiga memenuhi indikator berpikir kreatif fluency. Kemudian cara yang kedua mencari nilai $n$ terlebih dahulu menggunakan rumus $U_{n}=$ $U_{1}+(n-1) b$ untuk menghitung $S n=\frac{1}{2} n\left(U_{1}+U_{n}\right)$ dan cara yang ketiga 
menggunakan rumus $S n=\frac{1}{2} n\left(U_{1}+\left(U_{1}-(n-1) b\right)\right.$. Hasil yang diperoleh pada penghitungan cara kedua dan ketiga sama dengan cara pertama, maka subjek ketiga memenuhi indikator berpikir kreatif flexibility. Sedangkan pada soal nomor 2, langkah pertama mencari $n$ menggunakan $U_{n}=6 n$, selanjutnya mencari jumlahnya dengan rumus $S n=\frac{1}{2} n\left(U_{1}+U_{n}\right)$. Kedua menggunakan rumus $S n=\frac{1}{2} n\left(U_{1}+\left(U_{1}+\right.\right.$ $(n-1) b)$. Ketiga menggunakan rumus $S n=\frac{1}{2} n(2 a+(n-1) b$. Dari hasil pekerjaan subjek ketiga, rumus $S n=\frac{1}{2} n\left(U_{1}+\left(U_{1}-(n-1) b\right)\right.$ pada nomor 1 dan $S n=$ $\frac{1}{2} n\left(U_{1}+\left(U_{1}+(n-1) b\right)\right.$ pada nomor 2 , dihasilkan dari pemikiran subjek sendiri dan tidak ada subjek lain yang menggunakan rumus tersebut maka subjek ketiga memenuhi indikator berpikir kreatif novelty pada kedua soal. Hal ini sesuai dengan penelitian Siswono (2011) yang menunjukkan bahwa terdapat subjek yang dapat memenuhi indikator berpikir kreatif kebaruan (novelty).

\section{SIMPULAN DAN SARAN}

Sesuai dengan hasil pembahasan dan temuan-temuan yang diperoleh selama proses penelitian diperoleh kesimpulan bahwa seluruh subjek penelitian mampu memenuhi indikator berpikir kreatif kefasihan (fluency) dan keluwesan (flexibility) dalam menyelesaikan soal barisan dan deret aritmatika, sedangkan indikator berpikir kreatif kebaruan (novelty) dapat dipenuhi oleh dua subjek dari tiga subjek keseluruhan yaitu subjek kedua dan ketiga.

Berdasarkan hasil penelitian disarankan kepada peneliti lain untuk mengkaji lebih jauh mengenai kemampuan berpikir kreatif menggunakan soal open-ended dengan memberikan indikator soal yang lebih baik sehingga memunculkan jawaban yang bervariasi dengan cara atau strategi yang berbeda antar subjek dan konsistensi dengan hasil yang diperoleh.

\section{DAFTAR RUJUKAN}

Ayllón, M., Gómez, I., \& Ballesta-Claver, J. (2016). Mathematical Thinking and Creativity Through Mathematical Problem Posing and Solving. Propositós y Representaciones, 4(1), 169-218.

Becker, J. P., \& Epstein, J. (2006). The “Open Approach" to Teaching School Mathematics. Journal of the Korea Society of Mathematical Education. Research in Mathematical Education, 10(3), 151-157.

Fardah, D. K. (2012). Analisis proses dan kemampuan berpikir kreatif siswa dalam matematika melalui tugas open-ended. Jurnal Kreano, 3(2). 
Febriyanti, U. A., Hobri., \& Setiawani, S. (2016). Tingkat berpikir kreatif siswa kelas vii dalam menyelesaikan soal open-ended pada sub pokok bahasan persegi panjang dan persegi. Jurnal Edukasi UNEJ, 3(2), 5-8.

Firdaus., As'ari, A. R., \& Qohar, A. (2016). Meningkatkan Kemampuan Berpikir Kreatif Matematis Siswa SMA melalui Pembelajaran Open-Ended pada Materi SPLDV. Jurnal Pendidikan, 1(2), 227-236.

Firdausi, Y. N., Asikin, M. \& Wuryanto. (2018). Analisis kemampuan berpikir kreatif siswa ditinjau dari gaya belajar pada pembelajaran model eliciting activities (MEA). Prisma 1, Prosiding Seminar Nasional Matematika. 239-247. Diakses di https://journal.unnes.ac.id/sju/index. php/prisma/

Kang Sup, Lee., Dong-jou, Hwang., \& Jong Jin, Seo. (2003). A development of the test for mathematical creative problem solving ability. Journal of the Korea Society of Mathematical Education Series D: Research in Mathematical Education, 7(3), 163-189.

Koriyah, V. N., \& Harta, I. (2015). Pengaruh open-ended terhadap prestasi belajar, berpikir kritis dan kepercayaan diri siswa SMP. PYTHAGORAS: Jurnal Pendidikan Matematika, 10(1), 95-105.

Laela, I. (2017). Tingkat kemampuan berpikir kreatif siswa dalam menyelesaikan soal barisan dan deret kelas XI APK 3 SMK PGRI 1 Tulungagung tahun ajaran 2016/2017. Skripsi tidak dipublikasikan. Tulungagung: Institut Agama Islam Negeri (IAIN) Tulungagung.

Lince, R. (2016). Creative Thinking Ability to Increase Student Mathematical of Junior High School by Applying Models Numbered Heads Together. Journal of Education and Practice, 7(6), 206-212.

Mepnews. (2016). Peringkat PISA Indonesia naik tapi masih sangat rendah [Online]. Tersedia dari $\quad$ http://mepnews.id/2016/12/07/peringkat-pisa-indonesia-naiktapi-masihsangat-rendah/. Diakses 17 November 2017. Pukul 22.02.

Mrayyan, S. (2016). Investigating mathematics teacher's role to improve students creative thinking. American Journal of Educational Research, 4(1), 82-90.

Siswono, T. Y. E. (2011). Level of student's creative thinking in classroom mathematics. Educational Research and Review, 6(7), 548-553.

Siswono, T. Y. E. (2015). Desain Tugas untuk. Mengidentifikasi Kemampuan Berpikir Kreatif Siswa dalam Matematika. Tersedia dari https://www.researchgate.net/ publication/242735927. Diakses 8 Oktober 2015.

Sugiyono. (2012). Metode penelitian kuantitatif, kualitatif dan R \& D. Bandung: Alfabeta.

Wijaya, A. (2012). Pendidikan Matematika Realistik Suatu Alternatif Pendekatan Pembelajaran Matematika. Yogyakarta: Graha Ilmu 